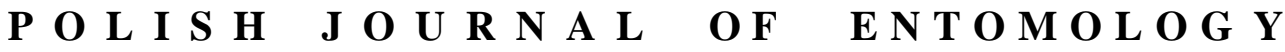

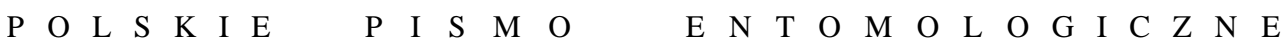

VOL. 83: $207-218$

Lublin

30 September 2014

DOI: $10.2478 /$ pjen-2014-0016

\section{Tortricidae (Lepidoptera) of the Afrotropical fauna: accession 1}

\author{
JÓZEF RAZOWSKI ${ }^{1}$, JANUSZ WOJTUSIAK $^{2}$ \\ ${ }^{1}$ Institute of Systematics and Evolution of Animals PAS, Sławkowska 17, 31-016 Kraków, \\ Poland, e-mail: Razowski@isez.pan.krakow.pl \\ ${ }^{2}$ Zoological Museum, Jagiellonian University, Ingardena 6, 30-060 Kraków, Poland
}

\begin{abstract}
Tortricidae are discussed; 6 species are described as new: Choristoneura saotome sp. n., Afroploce bagamoyo sp. n., Anthozela macambrarae sp. n., Anthozela usambarae sp. n., Eucosmocydia terreirana sp. n. and Cydia amaniana sp. n. Faunistic data on 12 species are provided.
\end{abstract}

KEY WORDS: Tortricidae, new species, faunistics, Afrotropics.

\section{INTRODUCTION}

This paper constitutes the first part of a series proposed by the senior author devoted to the leafrollers of the Afrotropical region. It will include systematic, faunistic and biological data based on various small collections insufficiently large to undertake faunistic studies of the countries or regions concerned or systematic revisions of genera or tribes. The "accessions" should be of importance for a further comprehensive revision of the fauna of tropical Africa, which generally has been rather superficially studied. However, progress on the systematics of the tortricines of this area has recently been made thanks to the publications of a number of authors (RAZOWSKI \& BROWN 2012).

\section{Acknowledgements}

The authors thank Mr Witold ZAJDA for dissecting the specimens and Mr Artur CZEKAJ, Kraków for taking the photographs and arranging the plates. 


\section{MATERIALS}

The present part includes material collected by the junior author in Tanzania, Principé Island and São Tomé Island.

The collection under study is deposited at the Museum of the Jagiellonian University, Kraków together with the vaste collection by J. WOJTUSIAK done during his stay in Nigeria.

Abbreviations used: GS - genitalia slide; MZUJ - Muzeum Zoologiczne Uniwersytetu Jagiellońskiego (Zoological Museum of the Jagiellonian University).

\section{SYSTEMATICS}

\section{Tortricinae}

\section{Choristoneura saotome sp. $\mathrm{n}$.}

(Figs 1, 2, 7, 10, 11)

\section{Diagnosis}

C. saotome is closely related to $C$. dinota (MEYRICK, 1918); saotome may be distinguished by its much larger size, paler hindwing, slender base of the uncus, strong median lobe in the middle of the sacculus and the minute signum.

\section{Description}

Wing span $24 \mathrm{~mm}$. Head and thorax rust brown. Forewing not expanding terminad; costa strongly convex at base, then weakly so (terminal part of wings damaged). Ground colour brownish cream sprinkled and suffused brown. Markings brown with dark brown edges consisting of remnants of basal blotch, broad median fascia convex medially, and small subapical and subterminal spots. Hindwing (worn) brownish; cilia paler.

Variation. Female wing span $26-28 \mathrm{~mm}$. Costa convex basally; termen hardly concave beneath apex, not really oblique. Ground colour brownish to rust brown; markings browner; median fascia expanding medially; cilia paler than markings. Hindwing brownish cream to grey-brown with indistinct strigulation in apical third; cilia creamer.

Male genitalia (Figs 1, 2). Basal part of uncus slender (posterior part damaged); socius slender; arm of gnathos broad, terminal plate large, curved; valva broad, oval; sacculus broad, somewhat convex medially, with large dorsal lobe beyond middle and curved free termination; median lobe of transtilla small; aedeagus rather short, with weakly curved, weakly thorned dorsal process.

Female genitalia (Fig. 7). Proximal part of sterigma rounded, postostial part expanding distally, with median plate and curved lateral arms; ductus bursae slender with long cestum; signum small. Subgenital sternite with distinct posterior sclerites marked by an oblique fold. 

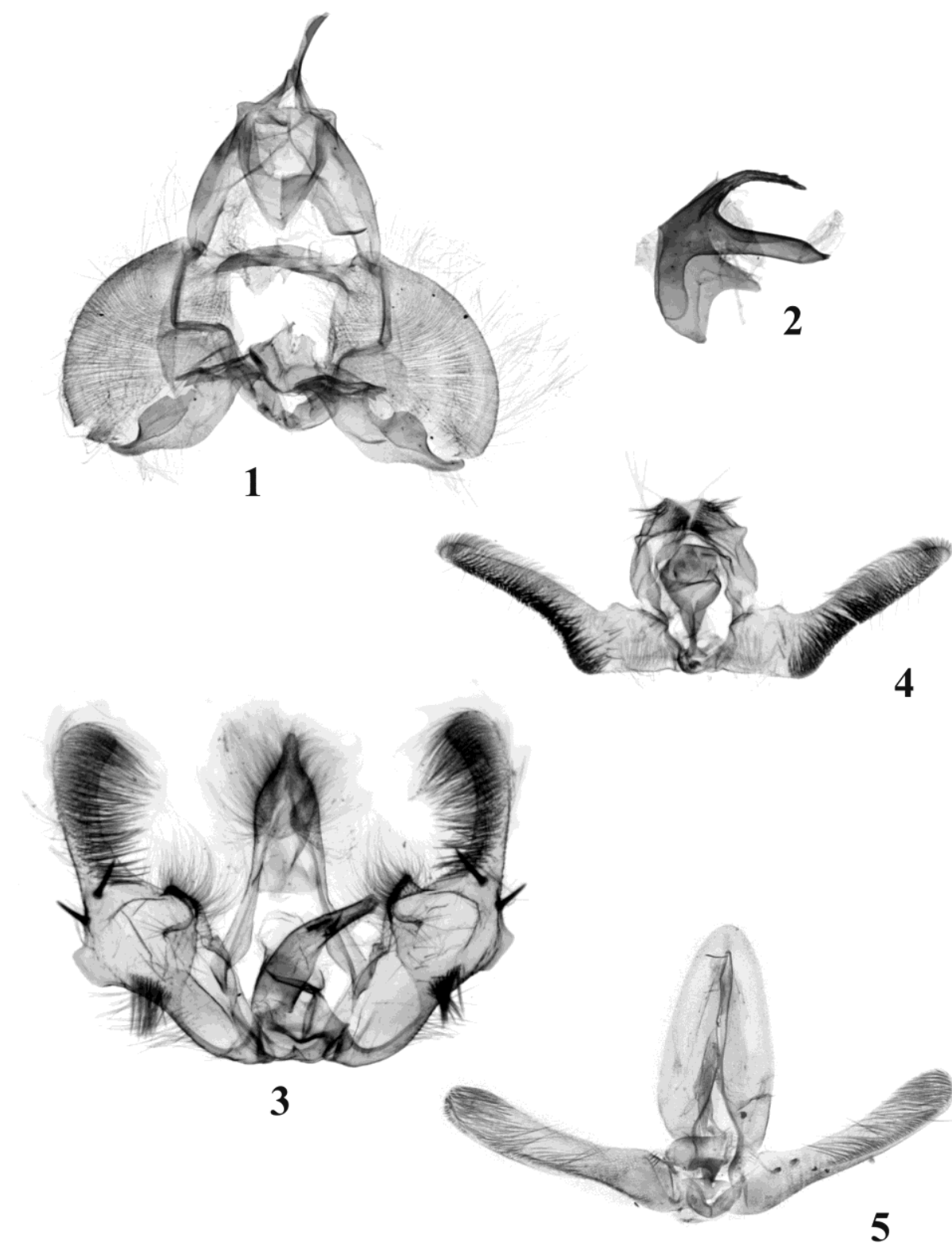

Figs 1-5. Male genitalia: 1, 2 - Choristoneura saotome sp. n., holotype, 3 - Afroploce bagamoyo sp. n., holotype, 4 - Anthozela usambarae sp. n., holotype, 5 - Eucosmocydia terreirana sp. n., holotype. 


\section{Material examined}

Holotype male: "São Tomé, Macambrara, 4. I. 1993, leg. J. WOJTUSIAK”; GS 1397 MZUJ. Paratypes 3 identically labelled females.

Etymology

The specific epithet derives from the name of the island, its terra typica.

\section{Choristoneura heliaspis (MEYRICK, 1909)}

\section{Material examined}

Two specimens from Tanzania (Mandera, $150 \mathrm{~km} \mathrm{~W}$ of Bagamoyo, 15. XI. 1988).

\section{Remarks}

C. heliaspis was described from Natal, South Africa.

\section{Choristoneura dinota (MEYRICK, 1918)}

\section{Material examined}

One specimen from Principé Island (Terreiro Velho, 15. I. 1993).

\section{Remarks}

This species was described from Malawi.

\section{Chlidanotinae \\ Ebodina lithoptila (DIAKONOFF, 1960)}

\section{Material examined}

Two females from Tanzania (Mandera, $150 \mathrm{~km} \mathrm{~W}$ of Bagamoyo, 15. XII. 1988).

\section{Remarks}

E. lithoptila was described from Madagascar.

\section{Olethreutinae}

Episimus doctrinalis (MEYRICK, 1934)

\section{Material examined}

Two males from São Tomé Island (Macambrara, 4. I. 1993).

\section{Remarks}

E. doctrinalis was described from São Tomé Island.

\section{Cosmorrhyncha acrocosma (MEYRICK, 1908)}

\section{Material examined}

One pair from Tanzania (Mandera, Bogamoyo, $150 \mathrm{~km} \mathrm{W,} \mathrm{15.} \mathrm{XII.} \mathrm{1988).}$

\section{Remarks}

C. acrocosma was described from Nyassa; AARVIK (2004) provides its distribution. 

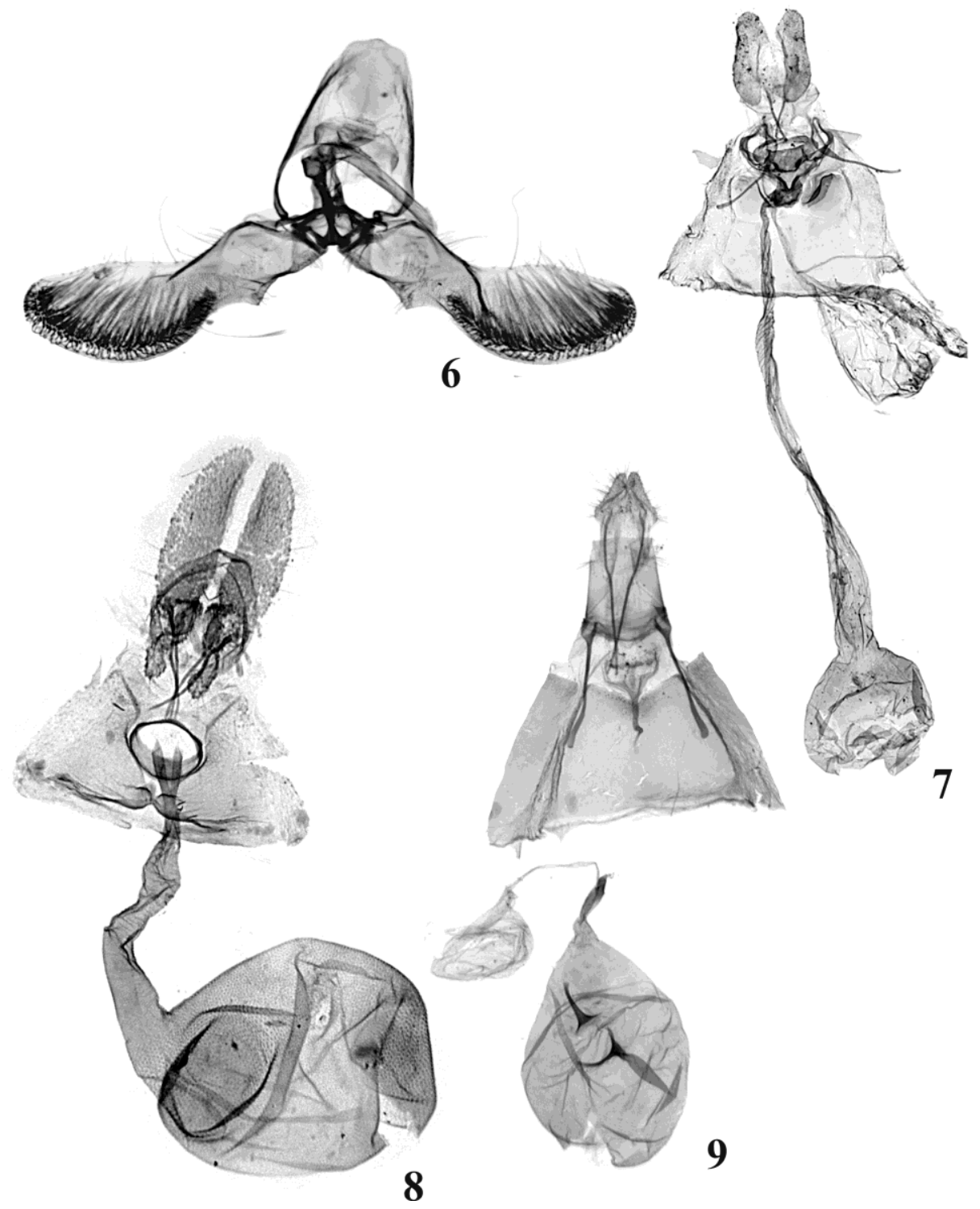

Figs 6-9. Male and female genitalia: 6 - Cydia amaniana sp. n., holotype, 7 - Choristoneura saotome sp. n., paratype, 8 - Anthozela macambrarae sp. n., holotype, 9 - Eucosmocydia terreirana sp. n., holotype. 


\section{Afroploce karsholti AARVIK, 2004}

\section{Material examined}

12 specimens from São Tomé (Bombaim, 8. VIII. 1993; Moro Peixe, 5. and 15. I. 1993) and Principé (Terreiro Velho, 15. I. 1983; 22.XII. 1992). One female from Tanzania (Mandera, $150 \mathrm{~km} \mathrm{~W}$ of Bagamoyo, 15. XII. 1988).

\section{Remarks}

This species is widely distributed, as it has been described from Tanzania, Malawi, Kenya, Ghana and Congo (Zaire). Also known from the Republic of South Africa.

\section{Afroploce bagamoyo sp. n.}

(Figs 3, 12)

\section{Diagnosis}

A. bagamoyo is related to A. mabalinguae RAZOWSKI, 2008 from the Republic of South Africa but bagamoyo has two strong spines at the base of the cucullus and a long aedeagus.

\section{Description}

Wing span $12 \mathrm{~mm}$. Head and thorax (rubbed) brownish with darker marks. Forewing slightly expanding terminad; costa almost straight; apex rounded; termen straight, moderately oblique. Ground colour cream sprinkled and suffused greyish brown. Markings: a diffuse much darker median fascia with blackish brown median and costal spots; subterminal and apical fascia concolorous. Cilia damaged. Hindwing cream grey; cilia (remnants) creamish.

Variation. Female $(27 \mathrm{~mm})$; ground colour cream with brownish yellow shade sprinkled and strigulated brown. Markings brown: basal blotch ill-defined consisting of spots and strigulae fused with broad median fascia, both connected by brownish dorsal suffusion; subterminal fascia small. Hindwing brownish; cilia somewhat paler.

Male genitalia (Fig. 3). Uncus distinct, tapering terminally; socius broad, lateral, both densely hairy; gnathos weakly sclerotized, simple; valva broad to end of sacculus which is convex postbasally, provided by a plate-shaped ventroterminal lobe beyond which there is one strong spine; another spine dorsad to the latter at base of cucullus; bunch of setae above concavity of sacculus; basal cavity broad with small hairy prominence subdorsally just beneath broad, hairy lobe; aedeagus large, slender, tapering terminally; cornuti two moderate spines.

Material examined

Holotype male: "Tanzania, Mandera, Bagamoyo/150 km W, 15. 12. 1988, leg. J. WOJTUSIAK", GS 1471.

Etymology

The name refers to the type locality. 

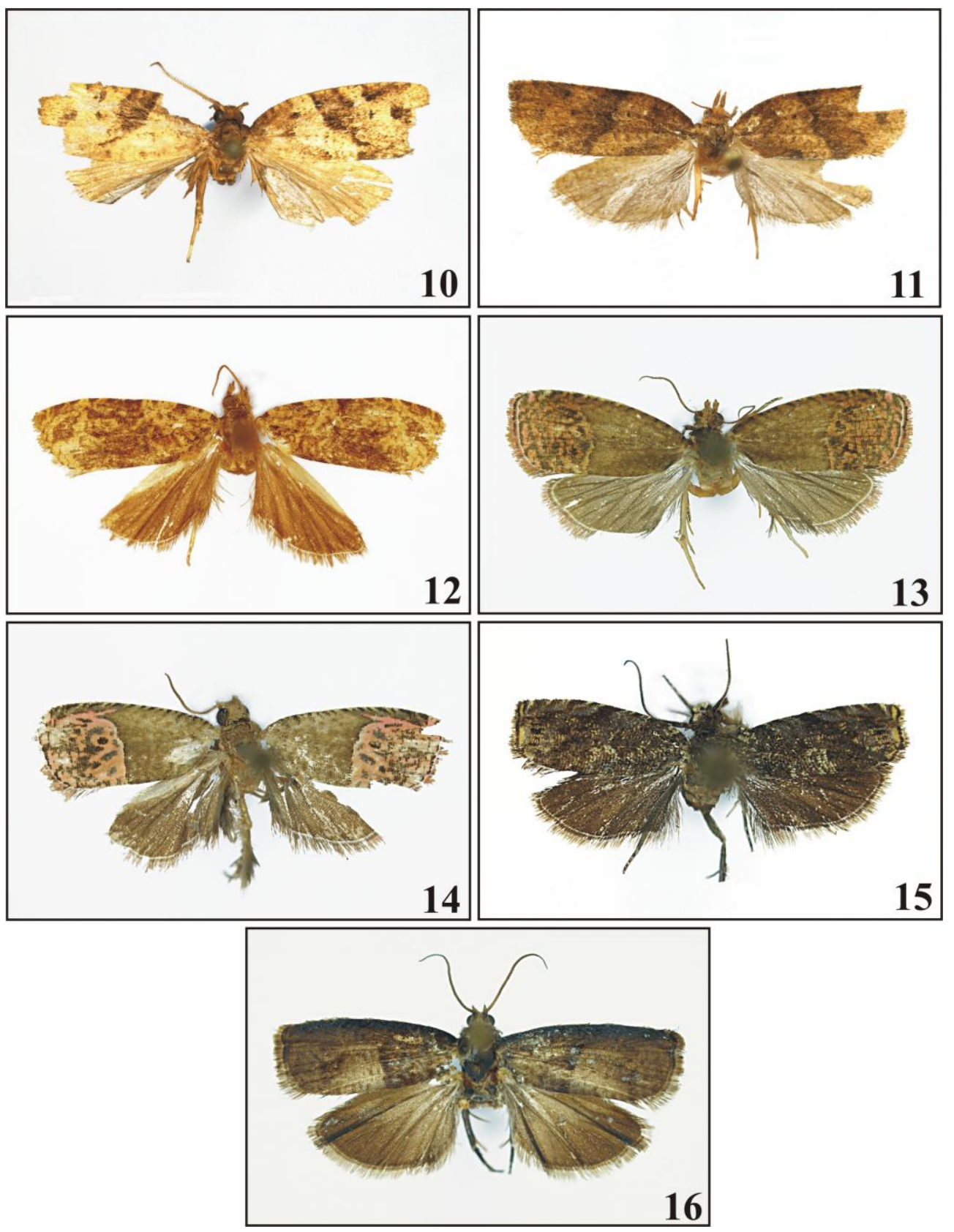

Figs 10-16. Adults: 10 - Choristoneura saotome sp. n., holotype, 11 - Choristoneura saotome sp. n., paratype, 12 - Afroploce bagamoyo sp. n., holotype, 13 - Anthozela macambrarae sp. n., holotype, 14 - Anthozela usambarae sp. n., holotype, 15 - Eucosmocydia terreirana sp. n., holotype, 16 - Cydia amaniana sp. n., holotype. 


\section{Cosmorrhyncha microcosma AARVIK, 2004}

\section{Material examined}

Five specimens from São Tomé (Macambrara, 4. and 15. I. 1993); one specimen from Principé Island (Terreiro Velho, 15. I. 1993); eight specimens from Tanzania (150 km W of Mandera/Bagomoyo, 15. XII. 1988).

Remarks

This species was described from Congo (Zaire), São Tomé, and Principé Island. AARVIK (2004) lists also Congo (Zaire) and Kenya.

\section{Lobesia vanillana (JOANNIS, 1900)}

\section{Material examined}

One male from Tanzania (Mandera, $150 \mathrm{~km} \mathrm{~W}$ of Bagamoyo, 15. XII. 1988) and one from Principé (Terreiro Velho, 15. I. 1993).

Remarks

L. vanillana was described from Réunion. It is widely distributed in this region.

\section{Syntozyga tryphera RAZOWSKI \& WOJTUSIAK, 2012}

\section{Material examined}

Three males from Principé (Terreiro Velho, 15. I. 1993) and São Tomé (Bombaim, 8. I. 1993).

\section{Remarks}

S. tryphera was described from Nigeria (states of Bendel and Anambra).

\section{Anthozela macambrarae sp. $\mathbf{n}$.}

(Figs 8, 13)

\section{Diagnosis}

In the facies, A. macambrarae is similar to the Nigerian A. prodiga RAZOWSKI $\&$ WOJTUSIAK, 2012 but the forewing of macambrarae has a more orange ground colour; the female of this species is characterized by strongly elongate papilla analas and a large, oval sclerite surrounding the ostium bursae.

\section{Description}

Wing span $15 \mathrm{~mm}$. Head brownish cream with slight orange hue; thorax browner. Forewing broad, weakly expanding posteriorly; costa gradually convex; apex rounded; termen not oblique, straight medially. Ground colour brownish cream with orange and olive admixtures delicately strigulated brownish grey; posterior part of wing pinkish separated from the former by a white convex line, marbled black; costal strigulae concolorous with ground colour to middle, pinkish posteriorly; divisions brown and blackish (posteriorly). Cilia pink 
with brown basal line. Hindwing brownish grey; cilia grey, in median part cream; basal line grey.

Male not known.

Female genitalia (Fig. 8). Papilla analis large with elongate posterior parts and short, slender proximal parts; eighth termite small; apophyses moderate; sterigma fused with lateral parts of subgenital sternite forming a sclerotized ring protecting ostium bursae which is slender posteriorly, followed by membranous postostial part; sclerite of antrum fairly long; ductus bursae broad proximally; signum plate-shaped.

\section{Type material}

Holotype male: "São Tomé, Macambrara, 4.01.1993, leg. J. WoJTUSIAK”; GS 1130 MZUJ. Paratype identically labelled female, GS 1235 MZUJ.

Etymology

The specific name refers to the type locality.

\section{Anthozela usambarae sp. n.}

(Figs 4, 14)

\section{Diagnosis}

In facies, A. usambarae is very similar to A. prodiga RAZOWSKI \& WOJTUSIAK, 2012 and A. postuma RAZOWSKI \& WOJTUSIAK, 2012 from Nigeria but is easily distinguished in the male genitalia, chiefly by the long, slender cucullus. Externally, it is also similar to Dichrorampha excisa WALSINGHAM, 1891 (genitalia not examined) from Gambia but has a pale yellowish brown anterior half of the forewing and more reddish brown, densely strigulated posterior half.

\section{Description}

Wing span $14 \mathrm{~mm}$. Head and thorax cream with olive grey admixture. Forewing broad, weakly expanding terminally; costa uniformly convex; termen rather straight, not oblique. Basal part of wing olive grey with sparse darker transverse strigulae, concave distally; posterior part pink marbled grey with around three blackish spots, apex pink; costal strigulae more cream than anterior half of wing except some terminal fragments which are cream; divisions brownish. Cilia (rubbed) pinkish. Hindwing pale brown; cilia creamish.

Male genitalia (Fig. 4). Terminal part of tegumen slightly concave; socius large, triangular, bristled; gnathos membranous; sacculus straight, angulate terminally; angle setose; cucullus long, slender, setose; aedeagus simple, fairly broad.

Female not known.

\section{Type material}

Holotype male: "Tanzania, Usambara Mts, Amani, 27. 12. 1988, leg. J. WoJTUSIAK”; GS 1456 MZUJ. Paratypes females: "São Tomé Is.[land], Macambrara, 04. 01. 1993, leg. J. WoJTUSIAK"; GS 1235 and female, same island, Moro Peixe, 5. I. 1993; GS 1128. 


\section{Etymology}

The name refers to the type locality.

\section{Neaspasia orthacta (MEYRICK, 1908)}

\section{Material examined}

Male and female from Tanzania ("Morogoro, Mandera, 15. 12. 1988, leg. J. WOJTUSIAK").

\section{Remarks}

$N$. orthacta is widely distributed in Africa and is already known from Tanzania. It is variable externally and also shows some slight differences in the genitalia. In the specimen examined the uncus is almost uniformly broad and the aedeagus slender.

\section{Eucosmocydia terreirana sp. $\mathbf{n}$.}

(Figs 5, 9, 15)

\section{Diagnosis}

In facies E. terreirana is similar to E. oedipus DIAKONOFF, 1988 from Madagascar; in the male genitalia the cucullus is long, slender, and the neck of the valva atrophied whilst in oedipus and E. prolixa RAZOWSKI \& WOJTUSIAK, 2012 the cucullus and the neck are distinct.

\section{Description}

Wing span $10 \mathrm{~mm}$. Head and thorax blackish brown; frons and posterior part of labial palpus white, basal half of palpus grey; strong brush of blackish brown scales in basal part of antenna. Forewing uniformly broad throughout; termen concave beneath apex, then convex. Ground colour whitish in form of dorsal patch consisting of four lines, yellowish patch at midtermen; otherwise brownish; two or three ocellar spots and refractive lines present; costal strigulae whitish, divisions brown; markings dark brown represented chiefly by median fascia. Cilia brownish cream with dark brown basal line. Hindwing dark brown; cilia yellowish brown at apex, whitish in anal area; basal line brown.

Variation. Paratype from São Tomé with paler elements of ground colour and better developed whitish sprinkling. The specimen from Bendel State has stronger parts of ground colour especially the postbasal fascia.

Male genitalia (Fig. 5). Tegumen tapering terminad; valva slender without neck; sacculus slightly convex; cucullus long, setose; aedeagus broad basally, slender, bent from beyond zone.

Female genitalia (Fig. 9). Apophyses posteriores long, slender, apophyses anteriores thick; sterigma built of strong membrane, rounded laterally; antrum membranous; ductus bursae slender; ductus seminalis originating before middle of the latter; blades of signa long, slender.

\section{Material examined}

Holotype male: "Principé Is.[land], Terreiro Velho, 15. 01. 1983, leg. J. WoJTUSIAK"; GS 1250 MZUJ. Paratype: one female from São Tomé, (Bombaim, 8. I. 1993). 


\section{Etymology}

The name is based on the name of the type locality.

\section{Cryptophlebia peltastica (MEYRICK, 1921)}

\section{Material examined}

One pair from Principé Island (Terreiro Velho, 15. I. 1983).

\section{Remarks}

This species is known from Nyassa, South Africa, Madagascar and Mauritius.

\section{Cydia amaniana sp. $\mathbf{n}$.}

(Figs 6, 16)

\section{Diagnosis}

C. amaniana is related to C. sennae RAZOWSKI \& BROWN, 2012 from Kenya and C. lissa RAZOWSKI \& WOJTUSIAK, 2012 from Nigeria but the angle of the sacculus of amaniana is triangular, not rounded.

\section{Description}

Wing span $17 \mathrm{~mm}$. Head brownish cream; thorax brown, tegula edged creamish. Forewing not expanding terminad; costa weakly convex; termen almost straight, incised beneath apex. Ground colour cream tinged brown; basal half of wing brown with some paler places with posterior edge convex subcostally; median area finely strigulated brown, becoming brown towards termen, with some dark brown strigulae. Cilia brownish. Hindwing brown, paler towards base; cilia brownish cream.

Male genitalia (Fig. 6). Tegumen with weak apical prominence; socii absent; gnathos in major part membranous; angle of sacculus subtriangular; cucullus large, elongate-oval; aedeagus moderately large, slender.

Female not known.

\section{Material examined}

Holotype female: "Tanzania, Usambara Mts, Amani, 27. 12. 1988, leg. J. WoJTUSIAK"; GS 1465 MZUJ.

Etymology

The specific epithet refers to the type locality.

\section{REFERENCES}

AARVIK L. 2004. Revision of the subtribe Neopotamiae (Lepidoptera: Tortricidae) in Africa. Norwegian Journal of Entomology 51(1): 71-122. 
RAZOWSKI J., BROWN J.W. 2012. Descriptions of new Tortricidae (Lepidoptera) reared from native fruits in Kenya. Zootaxa 3222: 1-27.

Received: 13 March 2014

Accepted: 1 July 2014 